\title{
A modern moral panic: the representation of British Bangladeshi and Pakistani youth in relation to violence and religion
}

\author{
By Rayen Salgado-Pottier (Goldsmiths, University of London)
}

\begin{abstract}
Moral panics have arisen about young British Pakistani and Bangladeshi males along two veins: violence and religion. Throughout this article I shall demonstrate that these young men should be considered modern 'folk devils', by placing them at the end of a succession of young deviants who have been repeatedly vilified. This is firstly explored through notions of ethnicity and criminality, via the analysis of media, government and public responses to 'gangs' and the 'riots' that took place in several northern industrial towns in the UK in 1995 and 2001, as well as Paris in 2005. Then the moral panic surrounding religion is explored, which seems to have overtaken the panic surrounding localised violence but still features the same protagonists. 'Islamophobia' is discussed in relation to xenophobic media and state representations of young Muslim men and how the latter interact with these derisive stereotypes. Exploring the increased interest of non-practising young Muslims in Islam, I suggest that this has had both beneficial and adverse consequences.
\end{abstract}

\section{Introduction: the folk devil}

The intellectual poverty and total lack of imagination in our society's response to its adolescent trouble-makers during the last twenty years is manifest in the way this response compulsively repeats itself and fails each time to come to terms with the 'problem' that confronts it. (Cohen 1987:204)

Successive generations appear to perpetuate myths about their youth being more violent and immoral than ever before. This 'deviancy amplification' (Cohen 1980:198) has been said to be the manifestation of a constant preoccupation with the breakdown of the moral order (Pearson 1983:209). From the white, working class male, through to the mods, punks and black urban youth, many have embodied the role of the 'folk devil', that is to say 'visible reminders of what we should not be' (Cohen 2002:2). It seems that Pakistani and Bangladeshi youth have now been accorded this role, erected in order to show members of society which roles should be avoided (ibid:1-2). This article will explore the representation of these young men in the United Kingdom via the two issues that have manifested themselves at the forefront of public and private concern: violence and religion. This has resulted in national and international moral panics, defined by Cohen (ibid:1) as follows: 'A condition, episode, person or group of persons emerges to become defined as a threat to societal values and interests; its nature is presented in a stylized and stereotypical fashion by the mass media.'

To begin with I shall examine the construction of Asian criminality and how this has been transposed onto fears about gang violence and Asian 'no-go' areas. The motif is 
then explored via the participation of Asian youth in the civil disturbances witnessed in the northern industrial towns in the UK in 1995 and 2001 and in Paris in 2005. This will be followed by a discussion of the moral panic surrounding Muslim youth, post global events such as the 11 September 2001 and 7 July 2005 attacks. Religion seems to have eclipsed the fear around small scale violence, but again the fear relates to young Bangladeshi and Pakistani males. And this time the panic is amplified by the global context in which it is played out. The latter undoubtedly impacts on young people's identity formation. Throughout the article the role played by the media, the government and academia in the representation (or misrepresentation) of young Bangladeshis and Pakistanis in Britain will be highlighted.

The primary sources used for this article come from the disciplines of sociology, criminology and anthropology. As evidence of the existence of a moral panic, I shall be using what Cohen (2002:vii) calls the 'three overlapping sources' that are crucial in establishing the basis of a moral panic. These are the moral panic itself, the commentary of the public and media in both long-term and short-term reflections, and thirdly the academic interpretation of the phenomenon from different viewpoints. This will include tabloid and broadsheet newspaper articles, speeches, government reports, interviews with the public as well as academic interpretations of events and anthropological ethnographies. Towards the end of the article I shall also draw very briefly on my own research conducted in 2006 in a youth club in Tower Hamlets (a relatively poor borough in east London). The youth club was predominantly attended by Bangladeshi young males and my research focused on the effect of Islamophobia on religious identity. It was a small-scale pilot study, which included participant observation, a quantitative questionnaire, as well as focus group and qualitative interviews. Any names mentioned are pseudonyms, so as to protect the anonymity of the respondents. I myself am a young female born in London and of Chilean and French background, who became interested in studying this area after having worked in my capacity as key worker (mentor) and youth worker with young people living in the UK of Bangladeshi heritage. It was also the larger international debates around Islamophobia and Muslim youth that precipitated my decision to conduct research in this field.

\section{A modern moral panic and the making of a folk devil?}

In this paper I suggest that young Pakistani and Bangladeshi males should currently be considered to be at the centre of a moral panic. This suggestion is based on theoretical reflections around youth subcultures and folk devils. Subcultural theory has its roots in the Chicago School of sociology, which examined the extraordinary diversity of human behaviour through the use of qualitative micro-sociological research in the 1920s (Thornton 1997:3). This eventually led to a British group of scholars called the Birmingham School, or the Centre for Contemporary Cultural Studies (ibid:6). Their theories suggested that youth deviancy was ultimately a reaction to the experience of growing up in a class society (Cohen 1980:xxv). They looked at specific groups such as mods, punks and others. Cohen (ibid:204) suggested that 'our society as presently structured will continue to generate problems for some of its members - working class adolescents - and then condemn whatever solution these groups find'. How do these subcultures relate to Pakistani and Bangladeshi youth today? 
If we accept that each generation has an 'immovable preoccupation with the erosion of social discipline and the corruption of the national character' focused around youth crime and violence (Pearson 1983:209), then each generation will in turn impose this preoccupation onto visually identifiable groups. Although in the eyes of the moral order these groups have transmuted into a more depraved and violent force than ever before, in effect it is just the names, appearance and symbols that change. However, in the past century 'ethnicity' has added another dimension to the equation. This has fuelled the already existing image of the 'foreign' folk devil. This phenomenon was seen in the late 1970s and early 1980s, when moral panics were perpetuated around the role of black youth in 'muggings' (Cohen 1980:xxi). As Pearson suggested at the time, this pattern of persecution is deeply ingrained in British consciousness: 'At the moment it is black people who stand accused of disrupting the peaceful traditions of the "British way of life"... But the English have been blaming their violence on someone else for a century or more' (Pearson 1983:x). This creation of a foreign folk devil highlights the fears of the British moral order:

The racist gallery of folk devils, and the differential or cultural racist fantasies of which they are constituted, are mere façades disguising more unitary, fundamental processes in which a constellation of Others-Blacks, Jews, Liberals, Asians, Muslims - is constructed as a threat to the purity and order of the nation, the ethnos, seen as a moral community. (Werbner 2005:6)

The 'Asian community' stands in contrast to this. 'Asian' here refers to the British use of the term, which includes South Asia and therefore many distinct nationalities, regions, religions, castes and languages (Pearson and Patel 1998:205), and is used in a broad sense. (In addition let me note that 'community' raises issues around connotations of homogeneity, which ignore specificities such as class, gender and differences in opinion [Burlet and Reid 1998:271].) The 'Asian community' and their youth have in the past been upheld as a 'model minority' (Back and Keith 1999:133) who embodied traditional working class values. Yet this was an oxymoronic presentation, in that despite the cultural traditions that gave 'Asians' the advantage over the post-modernist pathologisation of black youth (Gilroy 2002:140-141), there was still a problematic perpetuated about the second generation: "Afro-Caribbean" families are weak and disorganized, while their "Asian" equivalents are equally damned for being excessively durable and much too scrupulous in the tasks of cultural transmission' (Gilroy 2005:92). So the contradiction lies in that the 'Asian community' was at once upheld as contributing positively to the moral values of middle England, whilst equally being seen as a negative source of internal oppression over their young people (Alexander 2000:5). This 'oppression' reverberated with echoes of the idea that Asian and Islamic culture were in innate contradiction to western values and norms (cf. a 2005 survey in the UK, commissioned by The Daily Telegraph, in which 1 in 4 people thought that the beliefs of Western liberal democracy and the beliefs of Islam are fundamentally contradictory; YouGov 2005:2). We then witnessed Asian communities increasingly taking over the role of scapegoats, previously held by Britain's African-Caribbean communities, amidst renewed prophecies of millennial social doom (Alexander 2000:229). As Gary Younge, columnist in The Guardian, stated, it was both an ethnic and geographic shift from 'the south to the north and from Caribbeans to Pakistanis and Bangladeshis' (The Guardian, 10 July 2001).

Mac an Ghaill and Haywood (2005) observe that young Asians are still denied a sense of agency by government policy and academics alike in the formulation of their own 
identity, and in turn the perceived 'clash of cultures' is only couched in pessimistic terms:

There is a long history of race-relations experts informing policy makers of the assumed cultural conflict and identity crisis experienced by young Asians in Britain. They are projected as being 'caught between two cultures', which necessarily leads to psychological problems or the need to choose between their parents' traditional culture or that of Western culture in their place of residence. (Mac an Ghaill and Haywood 2005:7)

As a solution, Alexander (2000:217) suggests that academia must challenge the absolutist notions of 'the Asian community' or of the 'Between Two Cultures anomie', which reify Asian culture and young men into essentialist characteristics. The only mechanism that can challenge this is recognising the process of continuity and change, and in turn re-imagining the community in terms of ideas around gender and age.

However, a division lies within the term 'Asian'. Those of Indian background are seen as playing an active part in local business and politics (Baumann 1996:81). On the other hand, Bangladeshi and Pakistani communities are seen as the most disadvantaged group (Anwar 1998:190). Modood (1992) sees this division as occurring along religious lines: whereas Indians are seen as the 'achievers', Pakistanis and Bangladeshis are seen as the 'believers'. This is even felt on a grassroots level, evident in a comment made by a young Pakistani on why he sometimes chose 'Indian' as an ethnic category on job application forms: 'I even put, just changed my ethnic minority ... to make it a bit different. I think white people prefer Indian people [rather] than Pakistani' (Omair, quoted in Harris and Roach 2003:62). According to Alexander, Muslims are now becoming the most marginalised members of society: "Muslims have then, ironically, become the new "black" with all the association of cultural alienation, deprivation and danger that come with this position' (Alexander 2000:15).

There is evidence showing that Pakistani and Bangladeshi youth experience higher poverty and unemployment rates and are at present educationally underachieving (Anwar 1998:190). Mac an Ghaill and Haywood (2005:4) found that in Newcastle, Bangladeshis have the lowest household income, the highest number of persons per household rooms, the highest levels of unemployment and the highest level of multifamily households. Referring to both Pakistanis and Bangladeshis, Modood declares their position in no uncertain terms: 'If a racial underclass exists in Britain, here it is' (1992:261). While drawing comparisons with the wider population, society has been eager to find an explanation for this phenomenon. But how constructive is it to view these groups as a 'social problem, measured against the norm of the white majority population' (Mac an Ghaill and Haywood 2005:6) or against the Indian majority? Surely this is an example of cultural reification in which the dominant discourse stylises ethnic categories into homogenous groups, and can thus portray minorities as forming ethnic-cum-cultural 'communities' (Baumann 1996:16). The latter dominant discourse ignores cultural specificities such as religion, language, geography and social class (Burlet and Reid 1998:271).

Migration trends show that post-war immigrants from Pakistan and Bangladesh were from rural areas and migrated for reasons including economic necessity, social opportunities and career advancement (Mac an Ghaill and Haywood 2005:3). These two groups already possessed a lack of social mobility and were therefore more likely 
to fall into working class employment in Britain. Furthermore those settled in the northern towns were some of the first to be negatively affected by the breakdown of manufacturing industries in the 1970s (Mac an Ghaill and Haywood 2005:4, Rai 2006:92). Over the past three decades, first black, then Muslim Asian youth seem to have taken over the experiences and role ascribed to male white working class youth: unqualified, disaffected, and destined for manual work in our capitalist society (Willis 1977, cited in Cohen 1980:iv).

This parallel is further complicated when we consider the suggestion that Pakistani and Bangladeshi youth can also be described as being at the centre of a moral panic and therefore embody the role of the folk devil. In contrast to young white working class males, Pakistani and Bangladeshi youth are primarily defined by their ethnicity, in addition to dress, language or style. However, this should not lead us to believe that their class is unimportant. The Birmingham School emphasised class rather than any other factor as a defining feature of subcultures: 'Subculture was no less, a political battleground between classes' (Cohen 1980:iv). And, as Cohen clearly emphasises in 2002, the styles of contemporary young, working class males do not fall into particular visually identifiable groups as they once did.

There are two issues that lie at the heart of the moral panic surrounding young Bangladeshi and Pakistani men. The first centres around 'Asian criminality and gang formation' (Back and Keith 1999:133) and is based on an apparent increase in violent behaviour. This includes the disturbances such as those witnessed in Bradford in 1995 and Oldham in 2001. ('Disturbances' has been used here in the place of 'riots' or 'race riots', so as to avoid the disparaging connotations the latter terms carry as well as the sensationalist vocabulary used by the tabloids; Harris and Roach 2003:22-23.) Assertions such as the following exemplify this:

Over recent years young men of Pakistani origin and Muslim faith in Bradford have been increasingly involved in incidents of public disorder and violence. This represents a significant and consistent change over time in the direction of cumulative violence. (Macey 1999:853)

Macey's statement also points to religion as a contributing factor. This brings us to the second issue, which is Islam, and can be seen in the depiction of the younger generations as prone to 'reactive religious fundamentalism' (Alexander 2000:218). This moral panic is not just restricted to Britain. According to Aurore Wahlin from the London-based think tank Centre for European Reform, Muslims throughout Europe also face religious intolerance and xenophobia induced by fears of terrorism and globalisation (The Guardian, 9 November 2005). Nor is the rise of Islamophobia (the definition of this word shall be dealt with at a later stage) restricted solely to Europe. It is precisely the global context in which the panic is played out that amplifies the effects considerably. The themes of violence and religion do intertwine to some extent, but for the purposes of clarity they shall be treated in two separate sections below.

\section{The Molotov Cocktail: violence, the gang and riots}

I shall now examine ideas of violence, gang culture, criminality and civil unrest in relation to Pakistani and Bangladeshi youth. This is a relatively new societal and academic preoccupation, which began to emerge in the mid-1990s due to fears around gang violence and the disturbances that occurred in Bradford in 1995, known as the 
'Mannningham riots' (Harris and Roach 2003:22). As Alexander proposes, Asian young men had been largely invisible, presumed to be the beneficiaries of a rigid system of male hierarchy and privilege, in which the concerns were about the women, not men, due to the issues surrounding arranged marriages (Alexander 2000:5). Since then the young men have been propelled to the forefront of government concern with policies such as 'community cohesion' springing up. The media has also fuelled public angst proclaiming 'no-go' areas for whites and highlighting Asian territorial brutality: 'No-go Asians attack veteran' (The Telegraph, 24 April 2001).

The proclaimed rise in Asian criminality and violence, especially with regards to young Bangladeshis and Pakistanis, has now become one of the dominant motifs in recent reporting of race in the British media (Back 2002:367). Violence amongst Asian young men was put forth as a 'new phenomenon' (Alexander 2000:229) which had suddenly risen to epic proportions. According to Pearson (1983:5) this is the continuation of an endless cycle of myths surrounding violence: 'The allegation that such developments are somehow unprecedented, together with the feeling that they involve a massive historical shift, are entirely typical.'

Having said that, we also need to recognise that the disturbances in Bradford, Oldham and Paris, though not based on a 'new' phenomenon, still marked a shift. What exactly precipitated this change? Could it be that the 'second generation' is fighting back after decades of racial harassment?

They ... felt that their parents have, on the whole, tolerated prejudice, discrimination and harassment, perhaps at the price of settling in Britain. However, it appears that young Asians were not prepared to tolerate racial discrimination and harassment. (Anwar 1998:191)

Perhaps they are no longer willing to accept the explicit denigration that their parents once did (Gardner and Shukur 1994:163). This sentiment is evident in the following comment from Sylla, a young French Muslim, on why he participated in the Paris riots:

Our parents, they should understand. They did nothing, they suffered in silence. We don't have a choice. We're sinking in shit, and France is standing on our heads. One way or another we're heading for prison. It might as well be for actually doing something. (The Guardian, 9 November 2005)

It is said that as a solution to the experience of continual racism (cf. Bengali Backlash), offensive street violence is used to defend the community (Rai 2006:90). Ironically, the masculine model some young Asian Muslims have taken on, is actually that of the perpetrators of the harassment that they may be reacting against: 'It is interesting that the Bengali young men are accused of mirroring the exact forms of masculine embodiment associated with white working-class male culture' (Back and Keith 1999:136, cf. Rai 2006:91). Back and Keith conclude that the Bengalis' usurpation of white working class masculinity is perceived to be a major threat because it constitutes a violation of the 'white' code and 'white' territories, especially when a perceived 'no-go' zone for whites is established. Bengalis are then characterised as pro-active villains in a discourse which frames them as being 'the local folk demon, who use weapons, fight unfairly and act "flash"' (Back and Keith 1999:136). The past is quickly forgotten, and whites are framed as the victims of racial attacks. Furthermore it is claimed that they are denied rights due to positive discrimination and political correctness, a sentiment highlighted in the Cantle (2001) report (cf. Rai 2006:93). Sensationalist newspaper headlines regarding race and 
violence capitalise on white working class fears. So powerful is this discourse that it erases or elides the past, including the racial asymmetries that have existed and still continue to exist (Back and Keith 1999:151).

The groups created by Asian youth have often been labelled 'gangs', but is this the case? Alexander claims that the young people in her ethnography do not in any way constitute a 'gang' (2000:251). She highlights the mundane aspects of the young men's lives, often ignored by sensationalist tendencies: 'The ordinary and everyday are left invisible, unspoken and it is the extraordinary, the different, the deviant, which is made to stand, hypervisible and alone, for the experience, pure, untainted, authentic' (Alexander 2000:144-145). Here Alexander rejects the label ascribed by the media, academic and social researchers. But is this simply an example of an anthropological deconstruction of 'the gang' that obscures more than it reveals? Perhaps the criticism Cohen (1980:xv) makes of some subcultural theorists would be relevant: 'My feeling is that the symbolic baggage the kids are being asked to carry is just too heavy.' However demonised by the dominant discourses, a 'gang' might simply be viewed as what the dictionary definition entails: 'a group of youths from one neighbourhood banded together for social reasons' (Webster's New World Dictionary 1988). It is the connotations we attach to this label that make the term loaded. The fact that young Bangladeshis and Pakistanis are involved in gangs should not necessarily fuel the grossly exaggerated representations ascribed to them. What is certain is that the sensationalist and essentialist portrayals of Bangladeshi and Pakistani males have the effect of creating an immovable sense of anguish in the British psyche.

Public and media responses to the disturbances witnessed over the past decade involving young people mostly from Pakistani communities demonstrate this. The first of these disturbances occurred in 1995 in Bradford, over the arrest of four youths and the treatment of the community by the police (Burlet and Reid 1998:271). In 2001, a spate of disturbances branded 'race riots' took place in Bradford, Burnley and Oldham, and captured the British nation's imagination for a whole summer. Again in 2005, similar events were witnessed in the banlieues of Paris, but on a much grander scale, which lasted 12 nights, saw nearly 6,000 cars go up in flames, dozens of schools, community centres and shops wrecked, and 1,500 people arrested (The Guardian, 9 November 2005). The Paris events were sparked by the death of two youths apparently being pursued by the police. These events precipitated a flurry of public discourse as to the causes of the disturbances. As Back indicates, the media were quick to portray the young men as an irrational and destructive force:

The image of upturned cars on fire and a sea of protesters clashing with the police was plastered equally over the front pages of 'red top' and 'broad sheet' newspapers. The immediately striking thing about the coverage of these events was the way Asian young men were represented as an insurgent and violent mob. (Back 2002:368)

Blazing headlines such as 'Hundreds go on the rampage in Bradford' (The Daily Mail, 16 July 2001) and 'Police out in force after gangs clash in Oldham, racial tension flares up' (The Independent, 7 May 2001) demonstrated entirely customary traits of tabloid distortion. The journalistic tools used to exaggerate events included sensational headlines and melodramatic vocabulary, as well as deliberate heightening of certain elements in the story (Cohen 2002:19-20). But what was rather more unexpected were the distortions put forth by broadsheet newspapers. The role of the press in creating tension before and during the disturbances was highlighted in the 
subsequent inquiry chaired by Cantle (2001). This pointed to the media's part in producing 'inflammatory' articles that designated certain 'problem areas' (ibid:46), and published obviously racist views in the selection of letters by the editors (ibid:64). It is clear through these examples that the media occupies a powerful position in creating and labelling specific groups as deviant. As Cohen (2002) states, in their role as 'agents of moral indignation' they are able to raise feelings of panic whilst purporting to protect moral decency. This gives them the power of to create new rules and define social problems, which in this case has resulted in young Pakistanis of northern towns being branded as 'a monolithic and angry group, caught between two cultures, who were using violence as a means of empowerment' (Burlet and Reid 1998:281). I shall return to the question of empowerment below, when I discuss what the young people involved said about this.

What is noteworthy is the construction of some of the disturbances as 'riots'. Commenting on the 1995 and 2001 Bradford civil disturbances, some have suggested that the principal motivation behind the protests legally being classified as riots was so that the authorities could impose harsher sentences under the Riot Damages Act of 1886 (Burlet and Reid 1998:271, Worley 2005:48). Burlet and Reid (1998:271) argue that this label was contestable due to the number of people involved, the scale of damage and the claims by the young men that their initial intention was to protest against police racism. It seems that the media and the state intentionally represented these disturbances in the gravest manner in order to justify accusations of rootless violence and to implement the highest legal penalties possible. However, if we look to the causes of the disturbances, there is a seemingly endless list of justified reasons behind this unrest.

According to the Cantle (2001) report the disturbances arose amongst conditions of economic and social decline, added to geographical and cultural isolation felt by the residents of both Muslim and white working class neighbourhoods (cf. NYA 2002). The specific reasons behind the tension between white and Asian communities included extensive segregation between the communities in all aspects of education, housing, youth and community provision, which led to 'polarisation' (Cantle 2001:10). This resulted in communities leading 'parallel lives' (ibid:10). This was later denounced as 'myth making' by those pointing to more traditional patterns of wealth acquisition and subsequent moves to the suburbs, as well as mixed social activities (The Guardian, 5 November 2002). The Cantle (2001) review team also mentioned factors such as high levels of deprivation, seen in the poverty and unemployment young people face, poor relations with the police, competition for scarce resources and the role of the media. The report indicated that the civil unrest was an expression of frustration by young men who were disempowered and disenfranchised (cf. Burlet and Reid 1998).

Some disagree with this interpretation, arguing that material deprivation in itself does not explain public disorder or violence (Macey 1999:848). In reference to the 1995 disturbances, Macey goes on to justify this argument by asking why other members of the community (Pakistani women, non-Pakistanis and the 'whites') did not participate, considering they faced the same socio-economic conditions. Macey's (1998:850) reading of these disturbances is that young Pakistani male culture is intrinsically violent and uses Islam as a form of legitimisation. In my opinion, this reflects a pathologisation of Pakistani males, which prioritises individual responsibility over the unfavourable conditions these young men experienced. It refuses to take into account the considerable effect of racial harassment by the police and white communities, and 
it disregards the substantial pressure young men are under to find employment in comparison to women. It is precisely this type of neo-conservative interpretation that propels young Pakistani men to the centre of a moral panic, which in turn further marginalises them.

These views are not only confined to conservative academics. New Labour's response was characteristically pluralistic in its approach, such as in many other areas of policy, where the emphasis is placed on self-direction and 'responsibility' (Popple 1995:33). Debates arose around the acquisition of English language skills and British cultural identity (NYA 2002). In both the government's language and subsequent policies, there were critical undertones about the apparent lack of integration by ethnic minority communities. This meant that lack of contact became highlighted as a central motivating factor behind the disturbances, rather than issues of racism, deprivation and extremism (Worley 2005:487). Underlying New Labour's new concept of 'community cohesion', borne from the disturbances, was a policy linked to ideas of active citizenship and individual responsibility in relation to community (Worley 2005:483-484). This notion of 'citizenship' was linked with the need for 'a clear primary loyalty to this Nation' (Cantle 2001:20). This implies that those involved in the 'riots' had put their ethnic or religious identity first, instead of their national identity. As Worley $(2005: 488)$ states, the policy demonstrates features that are of grave concern, as it signals a move away from multiculturalism towards notions of assimilation. This harks back to the policies of the 1960s and 1970s, in which cultural differences were seen as a barrier to integration.

The voices of the young people concerned were omitted from these debates. How can we possibly interpret their actions if we ignore their views? As Back emphasises, others were eager to advocate on behalf of them:

A cacophony of other voices dominated the ink spilled in response and the airtime on radio and TV. It was the voices that dominated the media sound track that either spoke on behalf of the rioters' interests or condemned the young men as petty criminals. (Back 2002:368)

In retrospect, the few comments made by the young people were lucid and self-aware, such as the analysis of the violence in Paris by the young French Muslim quoted earlier, Sylla:

We burn because it's the only way to make ourselves heard, because it's solidarity with the rest of the non-citizens in this country, with this whole underclass. Because it feels good to do something with your rage. (The Guardian, 9 November 2005).

In the UK the 'riots' also represented a bold stance for young people's rights, which actually had an impact on subsequent relations with the police: 'I think ... the police have more respect for the Asian youngsters now' (Abdullah, quoted in Harris and Roach 2003:67). Another young man elaborates on this point and explains that although racism and discrimination still forms part of their everyday experience, young Pakistanis feel they have had an impact, however minimal:

I reckon they've [the police] learnt from that riot ... 'cos we have to get our voices across ... they've not listened. They've developed a fear in their hearts because the shit still goes on, the Asians still get battered outside, the Asians still get pulled over just 'cos he's got a flashy car, you still get the same, right ... But they have put a fear in their heart because certain areas they won't go into. (Salman, quoted in Harris and Roach 2003:40) 
It seems the riots constituted a search for respect and recognition, from both real and perceived adversaries (Rai 2006:92), and in this sense did in fact give a sense of empowerment - though frequently this slipped into a tendency to take over the role of the aggressor.

Interestingly, the trigger point most often appears to have been relations with the police (cf. Macey 1999:849). This applies both to the 1995 and 2001 disturbances in the UK, as well as those in Paris. Looking at analyses of past 'riots' such as those in Brixton $(1981,1985,1995)$ and Toxteth (1981), the issues are clearly recurrent. The four themes that were at the centre of debates in regards to the latter riots were questionable policing in inner cities, cultural pathologisations of particular ethnic groups, socio-economic problems, and the acts as a political statement by a group of otherwise politically dispossessed and marginalised young people (Burlet and Reid 1998:278). It is fair to say that all of these motifs can be found in the debates surrounding the recent disturbances.

This reiterates that when it comes to deviance, subcultures and moral panics, modern Western society has been constructed in such a way that the underlying problems and subsequent reactions to these form a cyclical pattern. It is important to be aware of this because 'as long as we continue to believe that it is new ... we will be badly handicapped in our attempts to deal intelligently with the problem' (Pearson 1983:x). This leads government and community leaders to brand a section of politically disenfranchised and economically marginalised youth as mindless criminals (The Guardian, 10 July 2001). They fail to recognise that the 'delinquency' may be a collective solution to a structurally imposed problem (Willis 1977, cited in Cohen 1980:iv).

\section{Muslim youth and the symbiosis of 'Islamophobia' and 'extremism'}

Having explored how violence is represented, we shall now turn to religion. Islam and extremism are at the forefront of a global moral panic, which has resulted in a worldwide anti-Muslim backlash (Rai 2006:52). 'Extremism' as defined by the UK Foreign Office means:

support for terrorist attacks against British or western targets, or for British Muslims fighting against British allied forces abroad, but also 'arguing that it is not possible to be Muslim and British' $\ldots$ and advocating the creation of an Islamic state in Britain. (Rai 2006:17)

The shift in the perception of Islam in British consciousness can be traced back to the Rushdie affair in the late 1980s. No trajectory of Islam in Britain can be recounted without noting this defining moment, which shattered the conceptions of the Asian community as a passive and homogenous group (Alexander 2000:6) and precipitated fears of a 'fundamentalist' Muslim community (Modood 1992:261). (As Modood also notes, the use of the term 'fundamentalism', which implies 'militant Muslim', is frequently incorrect. In its proper use it should not be applied to Shia Muslims, but only to some Sunni Muslims who advocate a literal rather than metaphorical reading of the Quran; ibid:265.) Even before the Rushdie affair, however, a British preoccupation with the role Islam played in the lives of young Muslims already existed (Alexander 2000, Back and Keith 1999). Anxieties centred on popular Islamic movements involving Asian youth, which both invoked the British orientalist imagination as well as tapping into currents of Islamophobia (Back and Keith 
1999:133). More recently these anxieties have proliferated and catapulted Muslim youth into the spotlight.

Islamophobia has been defined as the intolerance of religion (Parekh 2002:247), of culture (Modood 1997:4) and of its people (Halliday 1999:898), although I believe it is a combination of the three and cannot be treated separately. Nevertheless Islamphobia represents Islam as being an anachronistic monolith, resistant to modern realities (Parekh 2002:247). One such example is the alarmism and simplification found in the media (Halliday 1999:892). The events of 11 September 2001 in New York and 7 July 2005 in London have allowed the media to construct Muslims within a narrower and more negative framework (Poole 2006:92). This is exemplified through the vilification of Muslims: 'Almost a quarter of Muslims believe 7/7 was justified' (The Daily Mail, 6 August 2006), to the perceived threat Islam poses to the moral order: 'Whites being lured into Islamic terror' (The Telegraph, 2 July 2006). Hyperbole feeds moral hysteria. For example in March 2005 The Sun printed the headline: '100s of terrorists in UK' (The Sun, 1 March 2005), yet 17 months later this number had increased significantly: '1,000 Brits ready to die' (The Sun, 11 August 2006). What is interesting in the latter headlines is the shift from 'foreign terrorist' to 'British terrorist'. Terrorists were previously depicted as Muslims with connections to Britain, but since approximately 2001, they are being depicted as being British Muslims (Poole 2006:96). This new preoccupation can be observed in headlines such as: 'Home-grown hatred is the greatest threat to our country' (The Daily Mail, 10 August 2006).

Misrepresentation is equally present in broadsheet newspapers, which are normally considered to veer away from such inflammatory opinions. A study of The Guardian in 1999 showed a large amount of juxtapositions of the word 'Islamic' with adverse words such as 'extremism', 'fundamentalism', and 'militants'. The effect of such juxtapositions is that certain stereotypes or assumptions are engraved onto the reader's subconscious mind, even if this is not the intention (Parekh 2002:170). The consequence is that even if an article is balanced, the constant barrage of essentialist articles leads to a set opinion:

Any reference to Muslims is likely to switch on the notion, implanted by numerous other stories, that most Muslims are terrorists and/or 'fundamentalists' in their interpretation and practice of their faith. It is difficult or impossible in these circumstances for a single news item to be absorbed on its own merit. (Parekh 2002:169)

Again it is not only the media, but also writers who play into the current anxieties of their reading public, who reinforce the misrepresentation (Halliday 1999:892-893). Misrepresentation is also fed to the media by the government, whose role in providing information on terror threats that later turn out to be false cannot be ignored (Miller 2006:49).

Furthermore, the government is placing the responsibility of defeating terrorism on the Muslim community. This is evident in Tony Blair's speech in which he proclaimed that the 'moderate majority' must take action: 'You cannot defeat this extremism through what a Government does. You can only defeat it within a community' (The Independent, 7 June 2006). Here once again the pluralistic 'rights and responsibilities' agenda emerges in which the Muslim community have the choice between collusion and pro-activity against terrorism. The effect of this 'you are with us or with them' approach is that any criticism of the government by Muslims is 
depicted as verging on the criminal (Poole 2006:97). This clearly places the emphasis on the 'Other' as the root of the problem and effectively dissolves the obligations of the state. Instead of asking questions about how Muslims and migrants are excluded by society, questions are asked about Muslims who refuse to integrate or become British, thus making their 'alien' values the problem rather than society's racist views (Worley 2005:490).

A further slippage in the government's policies can be found in their use of new terror legislation. After many arrests and only a fraction of prosecutions, it seems they are using their new powers discriminately: 'Under the cloak of the Terrorism Act the police are simply sweeping the Muslim community in the hope that they strike it lucky against an unknown threat' (Miller 2006:50). The combination of increased 'stop and search' tactics against Muslims (Burlet and Reid 1998:276) and an increase in xenophobic attacks against Muslims (Parekh 2002:62), results in the double victimisation of young Muslim males. Werbner believes this represents an unprecedented attack:

What we have, then, uniquely in the case of contemporary Islam, is an oppositional hegemonic bloc which includes intellectual elites and the consumerist masses, as well as 'real' violent racists, like members of the British National Party, who exploit anti-Muslim discourses to target Muslims in particular (as statistics show) for racial attacks. (Werbner 2005:8)

So how do the young people themselves interact with these Islamophobic stereotypes? This shift in public, media and government opinion has had a strong influence on young Bangladeshi and Pakistani males and their sense of self. Whereas religion was previously another facet of their identity (Alexander 2000:245-246, Halliday 1999:896), they are now gaining an active interest in Islam. Following the events of 11 September 2001, there has been a predictable increase of interest in Islam among non-religious Asian youth (Glynn 2002:975). In such a climate,

victims of racism frequently turn to their religion for inner strength in their struggle against exclusion, abuse and non-recognition, particularly when their religion is being singled out for attack by racism as alien or inferior. (Parekh 2002:238)

As one young person commented:

Because I had a brown face, people thought I had some inside info. It made me read up on my religion and start making changes to myself, to stand up and be seen as a Muslim. (Faiza, quoted in Rai 2006:84).

During my research as a youth worker I frequently saw this connection. Speaking about the furore caused by the Danish cartoons depicting Mohammed as a terrorist, one person said to me: 'I have seen the debates spark off interest. Islamophobia has had the effect that more people including the young people want to learn about Mohammed and Islam.'

The coverage of Muslim oppression worldwide may lead to identification with the ummah, the international Muslim community. As a young Muslim put it: 'We were born in Britain and raised in a different political climate [to our parents]. We know what's been going on in Bosnia, in Afghanistan, and as Muslims it hurts us' (Asif, quoted in Rai 2006:96). The young Bengalis and Pakistanis that I worked with in east London have now integrated being 'Muslim' as a principal aspect of their identity. Evidence of this can be found in the results of a short survey I conducted. I asked 11 Bangladeshi males, 16 to 18 years old, to rate the importance of Islam to them on a 
scale of one (not at all important) to ten (very important); nine of them selected 10 , one selected 9 and one selected 8 on the scale. This was reinforced by a comment made by one respondent, an 18 year old Bangladeshi, after being asked if he had noticed any changes in the past five years: 'I wouldn't say there is more racism, but we definitely feel stronger about our religion.'

The benefit of a revival of interest in Islam is that Muslim youth organisations have experienced an increased interest. One of the organisers at the Young Muslim Organisation in east London commented as early as November 2001: 'rather than saying, "Oh, these are the practising brothers again, they're going to say the same thing", they're listening and they're saying, "How can we help?"' (Marouf, quoted in Glynn 2002:975). These Muslim organisations are giving young people previously involved in violent gangs, crime or drugs an attractive alternative. As one young person concluded: 'It gave me a lifeline' (Nazmul, quoted in Glynn 2002:979). Similar experiences of young Bangladeshis' search for an assertive Muslim identity (Rai 2006:97) can be found in my research. It is evident that the combination of youth work and Islam after 2001 has frequently proved an effective way of reaching disaffected Muslim youth and has been able to fulfil the desire for a more positive Muslim identification (Glynn 2002:970).

The change in approach to Islam among young people could be grounded in the tendency for young British Muslims to find the faith of their parents devotionally too simple, and politically too accommodating (Modood 1992:271). A contrast can be observed between second-generation Pakistanis in the 1980s, who embraced a secular political identity, and the current religious identity of young Pakistanis in Britain that has emerged after the Rushdie affair and 11 September 2001 (Hariss et al. 2003:25). The same can be applied to young Bangladeshis whose religious trajectory is quite different to that of their parents. Glynn (2002) states that some of the younger generation of Bangladeshis have shunned their parents' beliefs, founded in mystical Sufism from medieval India, as well as their battles for secularism and anti-racism, in favour of Islamist revivalist movements that place more emphasis on religion and its fundamentals, whilst denouncing arbitrary traditions. This proves to be attractive for some young people:

Islamic brotherhood is a real antidote to alienation, and the fight against real and perceived Islamophobia can unite the community in a common purpose in the same way that the fight against racism did previously. (Glynn 2002:975)

This has resulted in a new identity that combines political and religious ideology. Although this shift towards Islamism has been noted since the 1980s (Glynn 2002:973), there seems to have been an increase since 2001. Here it is important to point out that Islamism in itself is a broad term. Sayyid (2003:17) defines it as a 'discourse that attempts to centre Islam within the political order'. In the context of using Islam as a tool for community and individual empowerment he refers to Islamism as the assertion of a Muslim subjectivity, rather than the other end of the spectrum, i.e. a 'full-blooded attempt to reconstruct society on Islamic principles' (2003:17).

However, it seems that some fundamentalist organisations such as Jammet-e-Islami, Al-Muhajiroun and Hizb ut-Tahrir are capitalising on this newfound interest in Islam. I follow Tarlo $(2005: 17)$ in considering Hizb ut-Tahrir to be 'fundamentalist', which would also be in accordance with Modood's (1992) definition. The organisation was 
founded in order to revive and purify the ummah and to restore the Khilafah, the Islamic empire (Glynn 2002:987). Although some, such as Modood (1992) and Werbner (2002; cf. Shaw 2002) assert that those involved in radical Islam are mainly middle class, educated, urban immigrants, and that it is unlikely to have anything to do with racism and inner-city deprivation and violence, I would suggest that this pattern is now changing. In 2002, Glynn (2002) charted a change in the membership of Islamist movements from middle class to British-educated working class Bengali youth. This may be due precisely to the factors that Werbner (2002) denies. YuvalDavis (1997) connects the rise of fundamentalism amongst ethnic minorities in the West to the failure of nationalist and socialist movements to secure freedom from oppression, exploitation and poverty. Since socialism is not perceived to have offered a way out, working class anger is turning to other movements (Glynn 2002:977).

Certain events, it seems, have given extremist organisations more appeal amongst the young, such as Al-Muhajiroun, who are active in Tower Hamlets and university campuses. They claimed that 'Bin Laden did more for their recruitment in a few months than they had achieved in years of work on the campuses' (Glynn 2002:972). They sometimes actively play on the perceived dichotomy between national and religious identity. Hizb ut-Tahrir has sold CDs entitled Identity Dilemma in order to convince British Muslim youth of their alienation and exclusion from Western society (Tarlo 2005:13). Although Glynn's (2002) study found that the aforementioned group were considered fringe movements and there were very few members, the numbers may have increased more recently. Rai (2006) has also identified a process of 'selfradicalisation', as in the case of the young men involved in the London attacks of 7 July 2005, which were apparently spontaneous and self-generated. They were said to be inspired rather than directed by Al-Qaeda (ibid:156). An increase in radicalisation has somewhat been confirmed by security sources at MI5. They made a statement in 2006 saying that, post 11 September 2001, the number of people who are under suspicion for terrorist acts in the UK has increased threefold to 700 (The Independent, 10 May 2006). As discussed above, this needs to be interpreted with caution, and it could even be read as part of cynical propaganda strategies that serve to maintain the public consciousness at a high level of threat (Miller 2006:52). Nevertheless, during my research, a youth worker in east London saw this threat as very real: 'The young people I work with have been backed up into a corner by all this. It makes them more vulnerable and defensive and more likely to be angry.'

We need to understand the reasons behind this trend, something the current administration has been unwilling to explore publicly (Rai 2006:16). This is where the symbiosis of 'Islamophobia' and 'Islamic extremism' come into play. I would argue that the effects of this moral panic have, amongst other things, been an increase in Islamophobia, which thrives on the rhetoric of militant Islamism. Organisations wishing to promote radical Islamism then take advantage of the alienating effects of Islamophobia to promote themselves. This cycle may be endless: 'Islamic mobilization may breed more Islamophobia encouraging more mobilization on religious lines' (Glynn 2002:976). Therefore the latter two forms of extremism exist in a symbiotic relationship in which one gives an authoritative stance to the other: 'This may result in a vicious spiral of mutual hostility: cultural racism leads to an increased assertiveness among those at whom it is directed, and this in turn is perceived to justify further racism' (Parekh 2002:238). The consequences of this amplification cycle is that young Bangladeshi and Pakistani males are being increasingly ostracised and feel powerless (Rai 2006:161), which in turn makes them 
seek refuge and strength in their Muslim identity. This can benefit their lives and their community, but can also make them more vulnerable to extreme ideas and actions.

\section{Conclusion}

As modern folk devils, young Bangladeshis and Pakistanis represent the latest in a long line of youth who have been demonised by society. The unfortunate consequences of this is that it ostracises the young men and marginalises them further to the fringes of a moral order, which refuses to recognise its own destructive role in this process. Following disturbances and the use of violence, these young men have been represented as irrational and held individually responsible for their lack of allegiance to their British identity. I would argue that it is more appropriate to see the formation of gangs and the civil disturbances as a self-formed 'collective solution' (Willis 1977, cited in Cohen 1980:iv) to years of racial harassment, high levels of deprivation and lack of hope for the future. When it comes to religion, the global scale of alarm has greatly transformed the young men's religious identity. In reaction to heightened Islamophobic representations, many have found their religion to be a source of empowerment. The danger here is that the global animosity towards Muslims actually makes these young men more vulnerable to exploitation by extremist groups and self-radicalisation.

The implications of this for the media, the government, the police and some academic trends are that they can be partly held responsible for further alienating these young people from society. Anthropological and social research has a significant contribution to make in our understanding of the core issues at play. It is only through listening to the voices of the young people that a solution can be found so that they can consolidate a Muslim, Pakistani or Bangladeshi identity that sits comfortably within the current framework of what it means to be British. If this solution means the current framework must change, which in my opinion it does, then so be it. For if these identities continue to be represented as contradictory, we will continue to see generations of young Pakistanis and Bangladeshis being vilified by the moral order and subsequently becoming vulnerable to exploitation. However alarming the consequences of this moral panic, I would argue that in time this panic will eventually disappear from the public consciousness and that these young people will become folk devils of the past, who will remain a figure in the collective memory against which to compare the horrors of whoever will subsequently be given this societal role (Cohen 2002:2). In the meantime, which may be a considerable period for the young men concerned, we must understand, listen to and respect this group, so as to enable them to counter the derisive stereotypes and forge a constructive and empowering identity without turning into their previous harassers.

\section{References}

Alexander, C. 2000. The Asian Gang: Ethnicity, Identity, Masculinity. Oxford and New York: Berg.

Anwar, M. 1998. Between Cultures: Continuity and Change in the Lives of Young Asians. London: Routledge.

Back, L. 2002. Review of The Asian Gang: Ethnicity, Identity, Masculinity, by Clare Alexander. Journal of Ethnic and Migration Studies 28(2), 367-380. 
Back, L. and M. Keith. 1999. 'Rights and wrongs': Youth, community and narratives of racial violence. In New Ethnicities, Old Racisms (ed.) P. Cohen, 131-162. New York: Zed Books.

Baumann, G. 1996. Contesting Culture: Discourses of Identity in Multi-ethnic London. Cambridge: Cambridge University Press.

Bengali Backlash: Too Much Too Young. 1996. Arun Kumar. Somafilms / Channel 4, UK. 30 mins.

Burlet, S. and H. Reid. 1998. A gendered uprising: Political representation and minority ethnic communities. Journal of Ethnic and Racial Studies 21(2), 270287.

Cantle, T. 2001. Community Cohesion: A Report of the Independent Review Team. London: Home Office.

Cohen, S. $1980 / 1987 / 2002$. Folk Devils and Moral Panics, $1^{\text {st }} / 2^{\text {nd }} / 3^{\text {rd }}$ ed. Worcester: Basil Blackwell.

Gardner, K. and A. Shukur. 1994. 'I'm Bengali, I'm Asian and I'm living here!' The changing identity of British Bengalis. In Desh-Pardesh: The South Asian Presence in Britain (ed.) R. Ballard, 142-164. London: Hurst.

Gilroy, P. 2002. There Ain't no Black in the Union Jack. London: Routledge. 2005. Small Acts: Thoughts on the Politics of Black Culture. London and New York: Digisource.

Glynn, S. 2002. Bengali Muslims: The new East End radicals? Journal of Ethnic and Racial Studies 25(6), 969-988.

Halliday, F. 1999. Review article: Islamophobia reconsidered. Journal of Ethnic and Racial Studies 22(5), 892-902.

Harris, C. and P. Roach. 2003. Emergent Citizens? African-Caribbean and Pakistani Young People in Birmingham and Bradford. Leicester: The National Youth Agency.

Mac an Ghaill, M. and C. Haywood. 2005. Young Bangladeshi People's Experience of Transition to Adulthood. York: Joseph Rowntree Foundation.

Macey, M. 1999. Class, gender and religious influences on changing patterns of Pakistani Muslim male violence in Bradford. Journal of Ethnic and Racial Studies 22(5), 845-866.

Miller, D. 2006. Propaganda and the 'terror threat' in the UK. In Muslims and the News Media (eds) E. Poole and J. Richardson, 45-52. London and New York: I.B. Taurus.

Modood, T. 1992. British Asian Muslims and the Rushdie affair. In Race, Culture and Difference (eds) J. Donald and A. Rattanasi, 260-277. London: Sage Publications.

Modood, T. 1997. Introduction: The politics of multiculturalism in the New Europe. In The Politics of Multiculturalism in the New Europe (eds) T. Modood and P. Werbner, 1-24. London and New York: Zed Books.

NYA. 2002. Promoting Community Cohesion: The Role of the Youth Service. Leicester: National Youth Agency. 
Parekh, B. 2002. The Parekh Report: The Future of Multi-ethnic Britain. London: Profile Books; The Runnymede Trust.

Pearson, G. 1983. Hooligan: A History of Respectable Fears. Basingstoke: Palgrave Macmillan.

Pearson, G. and K. Patel. 1998. Drugs, deprivation, and ethnicity: Outreach among Asian drug users in a Northern English city. Journal of Drug Issues 28(1), 199-224.

Poole, E. 2006. The effects of September 11 and the war in Iraq on British newspaper coverage. In Muslims and the News Media (eds) E. Poole and J. Richardson, 89-102. London and New York: I.B. Taurus.

Popple, K. 1995. Analysing Community work: Its Theory and Practice. Buckingham: Open University Press.

Rai, M. 2006. 7/7: The London Bombings, Islam and the Iraq War. London: Pluto Press.

Sayyid, S. 2003. A Fundamental Fear: Eurocentrism and the Emergence of Islamism, $2^{\text {nd }}$ ed. London and New York: Zed Books.

Shaw, A. 2002. Why might young British Muslims support the Taliban? Anthropology Today 18(1), 5-8.

Tarlo, E. 2005. Reconsidering stereotypes: Anthropological reflection on the jilbab controversy. Anthropology Today 21(6), 13-17.

Thornton, S. 1997. General introduction. In The Subcultures Reader (eds) K. Gelder and S. Thornton, 1-10. London and New York: Routledge.

Werbner, P. 2005. Islamophobia: Incitement to religious hatred. Anthropology Today 21(1), 5-9.

Willis, P. 1977. Learning to Labour: How Working Class Kids Get Working Class Jobs. Lexington: Lexington Books.

Worley, C. 2005. 'It's not about race. It's about the community': New Labour and 'community cohesion'. Critical Social Policy: A Journal of Socialist Theory and Practice in Social Welfare, 25(4), 483-496.

YouGov. 2005. YouGov / Daily Telegraph survey results. Available at http://www.yougov.com/archives/pdf/TEL050101032 1.pdf

Yuval-Davis, N. 1997. Gender and Nation. London: Sage.

\section{About the author}

Rayen Salgado-Pottier completed an MA in Applied Anthropology, Youth and Community Work at Goldsmiths College in 2006. In 2002, she stumbled upon youth work in Mexico as a volunteer and has since worked with young people in London and India. Rayen is currently a full-time youth worker at City YMCA London and specialises in detached youth work and sexual health. She enjoys painting, yoga and kayaking. She can be contacted at rayensp@hotmail.com 